\title{
A highly unstable Holocene climate in the subpolar North Atlantic: evidence from diatoms
}

\author{
C. Andersen ${ }^{\mathrm{a}, \mathrm{b}}$, N. Koç ${ }^{\mathrm{a}, *}, \mathrm{M} \cdot$ Moros $^{\mathrm{c}}$ \\ ${ }^{a}$ Norwegian Polar Institute, N-9296 Tromsø, Norway \\ ${ }^{\mathrm{b}}$ Department of Earth Science, University of Bergen, Allégt. 41, N-5007 Bergen, Norway \\ ${ }^{\mathrm{c}}$ Bjerknes Centre for Climate Research, Allégt. 55, 5007 Bergen, Norway
}

\begin{abstract}
A composite record (LO09-14) of three sediment cores from the subpolar North Atlantic (Reykjanes Ridge) was investigated in order to assess surface ocean variability during the last $11 \mathrm{kyr}$. The core site is today partly under the influence of the Irminger Current (IC), a branch of the North Atlantic Drift continuing northwestward around Iceland. However, it is also proximal to the Sub-Arctic Front (SAF) that may cause extra dynamic hydrographic conditions. We used statistical methods applied to the fossil assemblages of diatoms to reconstruct quantitative sea surface temperatures (SSTs). Our investigations give evidence for different regional signatures of Holocene surface oceanographic changes in the North Atlantic. Core LO09-14 reveal relatively low and highly variable SSTs during the early Holocene, indicating a weak IC and increased advection of subpolar water over the site. A midHolocene thermal optimum with a strong IC occurs from 7.5 to $5 \mathrm{kyr}$ and is followed by cooler and more stable late Holocene surface conditions. Several intervals throughout the Holocene are dominated by the diatom species Rhizosolenia borealis, which we suggest indicates proximity to a strongly defined convergence front, most likely the SAF. Several coolings, reflecting southeastward advection of cold and ice-bearing waters, occur at 10.4, 9.8, 8.3, 7.9, 6.4, 4.7, 4.3 and $2.8 \mathrm{kyr}$. The cooling events recorded in the LO09-14 SSTs correlate well with both other surface records from the area and the NADW reductions observed at ODP Site 980 indicating a surface-deepwater linkage through the Holocene.
\end{abstract}

(C) 2004 Elsevier Ltd. All rights reserved.

\section{Introduction}

The North Atlantic circulation, through its heat transport and deepwater formation, is an important contributor in the climate system. Energetic water masses like the North Atlantic Drift (NAD) and its end-members transport heat from low to high latitudes, provide northwestern Europe and Iceland with mild climate, and control the freshwater budget in the area. Through numerous paleoclimatic investigations these important oceanic mechanisms have been shown to experience pronounced short-term and long-term changes during the last deglacial period (Lehman and

\footnotetext{
*Corresponding author. Tel.: +47-77-750-654; fax: +47-77-750501.

E-mail address: nalan.koc@npolar.no (N. Koç).
}

Keigwin, 1992; Koç Karpuz and Jansen, 1992; Bauch and Weinelt, 1997). Our present interglacial period has long been regarded relatively stable based on ice-core records (e.g., Dansgaard et al., 1993). This view of the Holocene period in the North Atlantic and adjacent areas is, however, being revised after evidence of millennial-scale climate fluctuations in atmospheric (O'Brien et al., 1995; Alley et al., 1997), marine (Bond et al., 1997; Bianchi and McCave, 1999; Giraudeau et al., 2000; Klitgaard-Kristensen et al., 2001; Jiang et al., 2002; Andersen et al., 2004) and terrestrial records (Denton and Karlén, 1973; Nesje et al., 2000). Even though the mechanisms behind millennial-scale climate fluctuations is still very much under debate, Bond et al. (1997, 2001) argued that the abrupt climate shifts during the deglacial and the Holocene cooling events occurred at intervals of about 1500 years and that they were a 
result of climate cyclicity independent from glacial influence.

In this study we present a reconstruction of Holocene sea surface temperatures (SSTs) from a composite of sediment cores located on the Reykjanes Ridge in the subpolar North Atlantic in order to quantify surface stability in this climatically sensitive region. Diatoms, which are siliceous photosynthetic algae, are utilized as surface monitors of paleo-oceanic conditions as they have been shown to reflect well the watermasses and temperatures of the area (Koç Karpuz and Schrader, 1990; Koç et al., 1993). Previous studies based on diatoms and alkenones from the Nordic Seas describe the general Holocene surface ocean climatic development as a period of cooling in step with the decreasing insolation at the northern hemisphere since 11,000 years B.P. (11 kyr) (Koç et al., 1993; Koç and Jansen, 1994; Birks and Koç, 2002; Marchal et al., 2002; Andersen et al., 2004). A Holocene climate optimum lasting from $9.5 \mathrm{kyr}$ until $\sim 6.5 \mathrm{kyr}$ is followed by a Holocene transition period from 6.5-3.0 kyr during which time the climate was deteriorating. During the Late Holocene Cooling from $3.0 \mathrm{kyr}$ to present SSTs stabilized around a mean with a variability of $1-2{ }^{\circ} \mathrm{C}$ (Andersen et al., 2004). The presence of millennial-scale coolings observed in different circum North Atlantic regions (Denton and Karlén, 1973; O’Brien et al., 1995; Bond et al., 1997; Giraudeau et al., 2000) do however indicate of a complex system with regions of different sensitivity.

The subpolar North Atlantic is an oceanographically dynamic area. The surface regime is strongly imprinted by the subpolar gyre, characterized by meridional (northward) and zonal (eastward) circulation (Fratantoni, 2001). The core site is situated on the western flank of the Reykjanes Ridge south of Iceland and is today at the margin of the warm Irminger Current (IC) (Fig. 1). The IC is the northwestern branch of the NAD and separates into two branches west of Iceland. While a small branch continues northward and flows around Iceland (Stefánsson, 1962; Hopkins, 1991) most of it turns southwest where it is incorporated into the West Greenland Current (WGC) (Hurdle, 1986; Fratantoni, 2001). The core site is located close to the SAF, which separates subpolar/subarctic water from warm Atlantic water. The front has a meander-like shape and is most strongly defined along the $53^{\circ} \mathrm{N}$ parallel. Further north the configuration of the front is less well constrained. Summer SSTs are normally between 11 and $12^{\circ} \mathrm{C}$ (Dietrich, 1969; Johannessen, 1986), but can vary due to the varying amounts of influence from subpolar water originating from the $\mathrm{EGC}$ or from the conjunction area between the WGC and the Labrador Current (LC) (Fig. 1). The site is thereby in a position to record the past strength and variability of the IC branch of the NAD and the SAF. The record provides both further evidence for, but also quantifies the magnitude of a series of Holocene cooling events that can be correlated to repeated southward intrusion of cold water into the North Atlantic reported in earlier studies (Bond et al., 1997, 2001; Giraudeau et al., 2000).

\section{Material and methods}

\subsection{Material}

The investigated material consists of one large boxcore (LO09-14 LBC; $0.4 \mathrm{~m}$ long), one giant gravity-core (LO09-14 GGC; $2.7 \mathrm{~m}$ long) and one gravity-core (LO09-14 GC; $5.6 \mathrm{~m}$ long), which were recovered from the same site on the Reykjanes Ridge $\left(58^{\circ} 56.3 \mathrm{~N}\right.$, $30^{\circ} 24.5 \mathrm{~W}$ ) (Fig. 1). The age chronology is based on a total of 34 AMS ${ }^{14} \mathrm{C}$ dates of the foraminifera Globigerina bulloides (Table 1). The ${ }^{14} \mathrm{C}$ dates were calibrated to calendar years before present by using OxCal Program v3.8 with Stuiver and Reimer marine calibration table (Bronk Ramsey, 1995, 2001; Stuiver et al., 1998). A marine reservoir age correction of 400 years is used in the calibration. The establishment of an agedepth model was done by linear interpolation between dated levels in the LBC and by polynomial fits for the GGC and the GC (Fig. 2a-c). Due to soft and waterrich sediments at the top of GGC sediments were squeezed out during sampling, hence there is a gap in the composite record between the LBC (at $1.25 \mathrm{kyr}$ ) and the GGC (at $2.2 \mathrm{kyr}$ ). Stacking GGC and GC make up a composite record covering the period from $\sim 2.2$ to $11 \mathrm{kyr}$. We sampled the LBC every $2 \mathrm{~cm}$, which produced a $15-60 \mathrm{yr}$ resolution. The GGC and the GC cover the time period from 2.2 and $11.2 \mathrm{kyr}$ and sampling intervals of $5-10 \mathrm{~cm}$ resulted in a time resolution varying from 50 and 350 years.

\subsection{Methods}

The diatom samples were prepared according to the methods described by Koç et al. (1993) and references therein. Laboratory processes involve acid treatment to remove carbonate and organic matter, neutralization of remaining acid, clay separation and preparation of quantitative slides. A Leica Orthoplan microscope with 100/1.32 magnification was used for identification and counting of the diatoms. Counting procedures described in Schrader and Gersonde (1978) were followed.

The downcore diatom data were analysed and described in terms of the previously expanded work of Koç Karpuz and Schrader (1990) (Andersen et al., 2004) (Fig. 3). Factor analysis of diatoms from the surface sediments of the Nordic Seas and the North Atlantic produced eight significantly different assemblages (factors). Mapping of the eight factors showed their close affinity to hydrographic regime of the area. Factor 1 is 


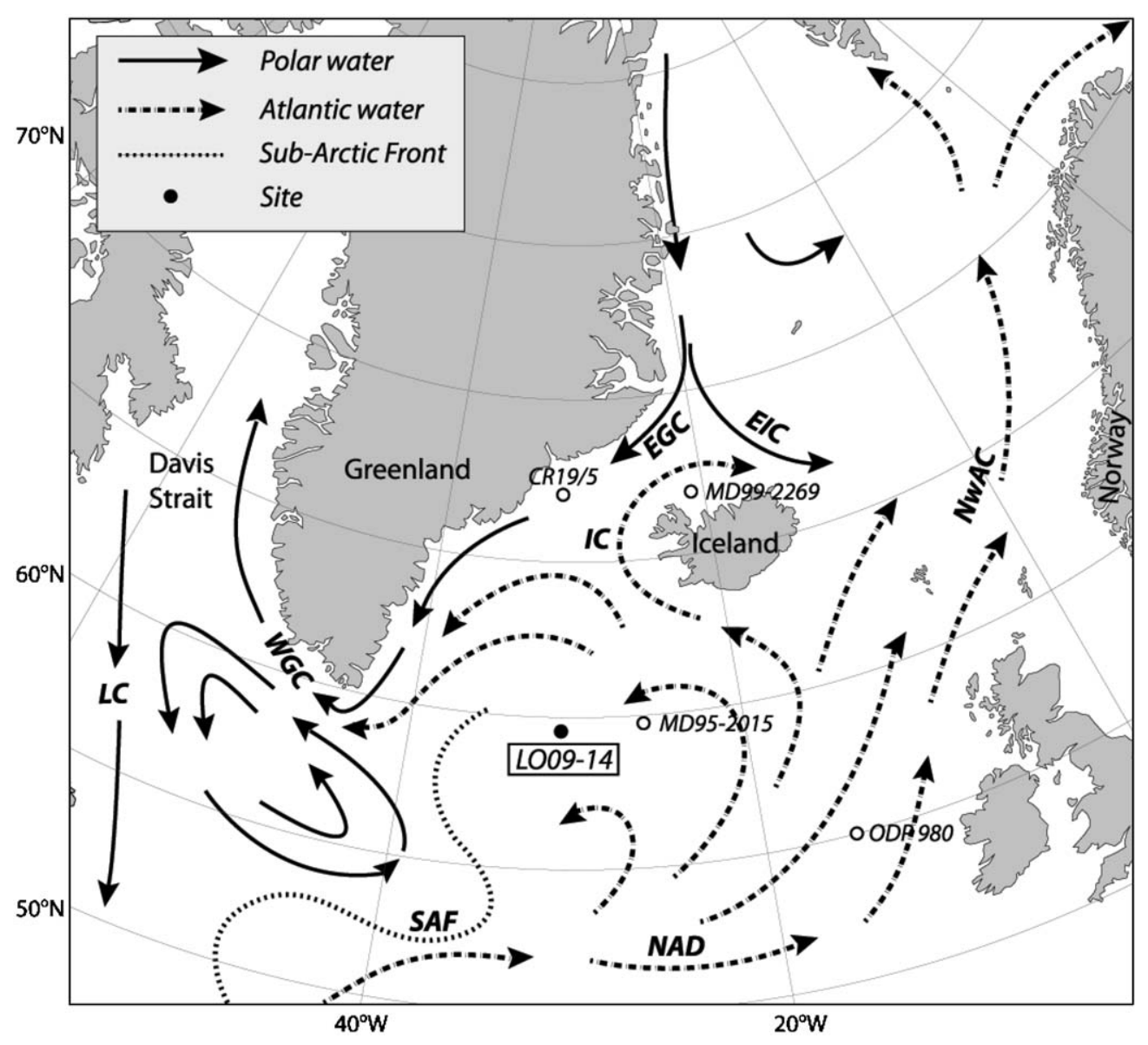

Fig. 1. Location of core site LO09-14 (filled circle) and the present-day pattern of surface currents in the area and the Sub-Arctic Front (SAF). Open circles show the sites of other records discussed in the text. NAD = North Atlantic Drift; IC = Irminger Current; NwAC $=$ Norwegian Atlantic Current; EGC = East Greenland Current; EIC = East Icelandic Current; WGC = West Greenland Current; LC $=$ Labrador Current. The figure is modified from Ruddiman and Glover (1975).

the Greenland Arctic Waters assemblage, which consists primarily of Thalassiosira anguste-lineata and Thalassiosira trifulta. Highest loadings of this factor occur in sediments underlying the Arctic waters of the Greenland Sea. Factor 2 is the North Atlantic Current assemblage and strongly reflects the distribution of a single species, Thalassiosira oestrupii. Other contributors to this assemblage are Thalassionema nitzschioides, Nitzschia bicapitata, Rhizosolenia bergonii, Roperia tesselata, and Nitzschia marina. Highest loadings of this factor occur under the warm and saline North Atlantic Current Waters. Factor 3 is the Subarctic Waters assemblage consisting primarily of Rhizosolenia hebetata f. semispina and to a lesser degree Rhizosolenia borealis and Thalassiothrix longissima. Highest loadings of this factor occur under the Arctic waters of the Iceland Sea and the Subarctic waters of the western North Atlantic. Factor 4 is the Norwegian-Atlantic Current assemblage consisting of Thalassionema nitzschioides as the main contributor, and Proboscia alata and Thalassiosira angulata as secondary contributors. Factor 5 is the Sea-ice assemblage consisting primarily of Nitzschia grunowii.
Other important species in this assemblage are Nitzschia cylindra, Thalassiosira hyalina, Thalassiosira gravida spores, Thalassiosira nordenskioeldii and Bacterosira fragilis. The spatial distribution of this assemblage mirrors the limit of the sea-ice edge in winter. Factor 6 is the Arctic Water assemblage consisting primarily of Thalassiosira gravida spores. Other important contributors to this assemblage are Thalassiosira gravida vegetative cells, Actinocyclus curvatulus, Rhizosolenia hebetata f. semispina and Rhizosolenia hebetata $\mathrm{f}$. hebetata. In the Nordic Seas highest loadings of this factor occur under the East Icelandic Current and the Jan Mayen Polar Current. In the North Atlantic highest loadings of this factor is found as a belt following the Sub-Arctic front. Factor 7 is the East- and WestGreenland Current Assemblage consisting mainly of Thalassiosira gravida vegetative cells. In the North Atlantic highest loadings of this factor is found under the Subarctic Waters of the Labrador Sea. Factor 8 is the Transitional Waters assemblage consisting mainly of Rhizosolenia borealis. Because of their close affinity to modern hydrographic regimes these factors enable us to 
Table 1

Radiocarbon dates and calibrated ages

\begin{tabular}{|c|c|c|c|}
\hline $\begin{array}{l}\text { Core name/Depth } \\
(\mathrm{cm})\end{array}$ & Lab no. & $\begin{array}{l}{ }^{14} \mathrm{C} \text { age } \pm \text { standard } \\
\text { deviation }\end{array}$ & $\begin{array}{l}\text { Calibrated Age } \\
\text { (Cal yr B.P.) }\end{array}$ \\
\hline \multicolumn{4}{|l|}{ LO09-14LBC } \\
\hline 0 & AAR-5049 & $705 \pm 40$ & 310 \\
\hline 2 & OS-32526 & $785 \pm 35$ & 425 \\
\hline 9 & OS-32140 & $1080 \pm 25$ & 643 \\
\hline 29 & OS-32475 & $1250 \pm 65$ & 795 \\
\hline 39 & OS-32474 & $1560 \pm 30$ & 1112 \\
\hline \multicolumn{4}{|l|}{ LO09-14GGC } \\
\hline 0.5 & AAR-6671 & $1190 \pm 35$ & not included \\
\hline 9 & OS-32477 & $2770 \pm 45$ & 2499 \\
\hline 17 & KIA7500 & $2495 \pm 25$ & 2151 \\
\hline 30 & OS-32478 & $2990 \pm 35$ & 2760 \\
\hline 47 & AAR-6437 & $2690 \pm 40$ & 2384 \\
\hline 69 & OS-32524 & $3030 \pm 35$ & 2793 \\
\hline 79 & OS-32525 & $2860 \pm 35$ & 2627 \\
\hline 101 & KIA & $3165 \pm 35$ & 2945 \\
\hline 120 & OS-32696 & $3260 \pm 45$ & 3081 \\
\hline 150 & KIA7501 & $4250 \pm 35$ & 4346 \\
\hline 163 & OS-32697 & $4680 \pm 50$ & 4907 \\
\hline 197 & OS & $5220 \pm 50$ & 5577 \\
\hline 240 & KIA7502 & $6440 \pm 35$ & 6913 \\
\hline 276 & KIA & $7180 \pm 40$ & 7636 \\
\hline \multicolumn{4}{|l|}{ LO09-14GC } \\
\hline 51 & KIA7497 & $5330 \pm 50$ & 5689 \\
\hline 103 & AAR-4454 & $6620 \pm 80$ & 7125 \\
\hline 135 & KIA20793 & $6920 \pm 40$ & 7450 \\
\hline 159 & KIA7498 & $6605 \pm 40$ & not included \\
\hline 165 & KIA20794 & $7435 \pm 40$ & 7860 \\
\hline 185 & OS-32681 & $7730 \pm 35$ & 8190 \\
\hline 216 & KIA7499 & $8005 \pm 40$ & 8457 \\
\hline 243 & OS-32690 & $8420 \pm 40$ & 8926 \\
\hline 270 & KIA20795 & $8385 \pm 45$ & 8920 \\
\hline 276 & AAR-5050 & $8145 \pm 45$ & not included \\
\hline 300 & AAR-4455 & $8790 \pm 100$ & 9324 \\
\hline 303 & OS-32691 & $9050 \pm 40$ & 9653 \\
\hline 315 & OS-32692 & $9040 \pm 45$ & 9638 \\
\hline 333 & OS-32693 & $9220 \pm 45$ & 9911 \\
\hline 370 & OS-32694 & $9350 \pm 40$ & 10029 \\
\hline 394 & AAR-5051 & $9310 \pm 55$ & 10003 \\
\hline 437 & OS-32695 & $9920 \pm 55$ & 10705 \\
\hline 447 & AAR-4456 & $10,410 \pm 90$ & 11366 \\
\hline
\end{tabular}

$\mathrm{OS}=$ Woods Hole Oceanographic Institute; AAR = Aarhus University; KIA = Kiel.

All measurements are made on the foraminifer species Globigerina bulloides.

Polynomial fits for the conversion from core depth $(\mathrm{cm})$ to time domain are: (i) $L 009-14 G G C$ : cal kyr $\quad \mathrm{BP}=2474-2.9 \mathrm{~cm}+$ $0.0222 \mathrm{~cm}^{2}+0.00084 \mathrm{~cm}^{2}-2.31 \mathrm{E}-006 \mathrm{~cm}^{4}, \mathrm{R}^{2}=0.987$ and (ii) $L O 09$ $14 G C: \quad$ cal kyr $\quad \mathrm{BP}=4221+33.95 \mathrm{~cm}-0.085 \mathrm{~cm}^{2}+9.61 \mathrm{E}-005 \mathrm{~cm}^{3}$, $\mathrm{R}^{2}=0.985$.

reconstruct details of the surface ocean variability. The downcore factors are then used in the temperature equations to estimate paleotemperatures. The estimations have a root mean square error of $1.25^{\circ} \mathrm{C}$, a coefficient of determination between observed and
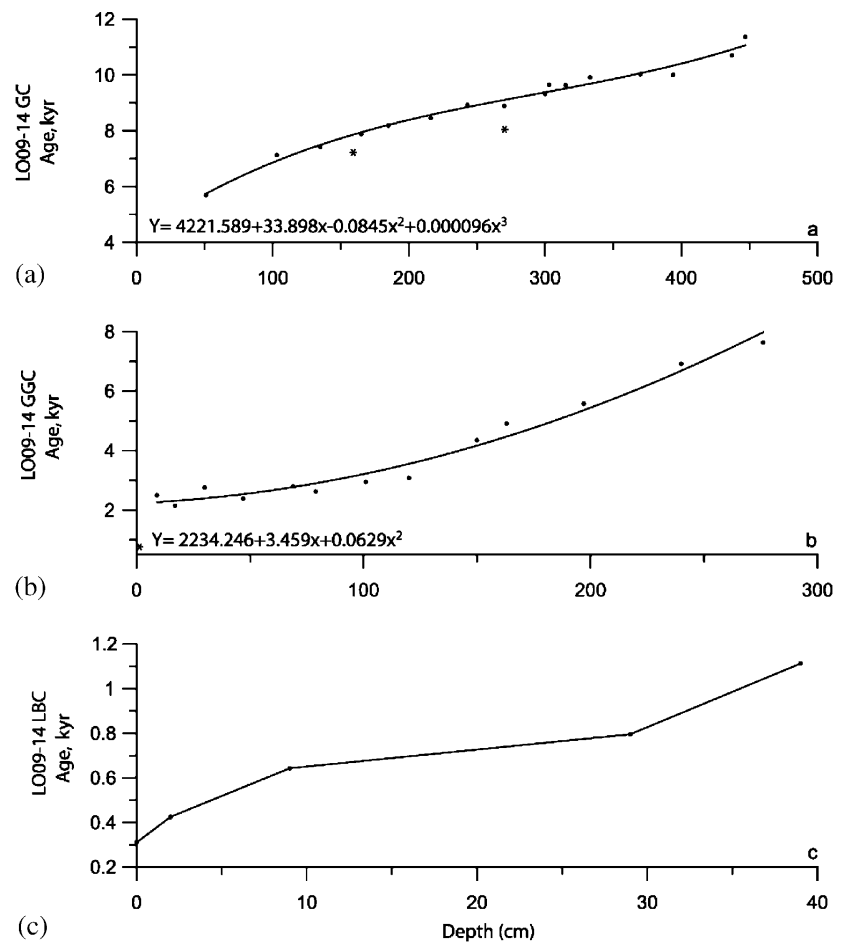

Fig. 2. The age-depth models for LO09-14 GC (a), GGC (b) and LBC (c) based on the dates presented in Table 1. Asterisk mark the excluded dates.

inferred SST of 0.89 , and a maximum bias of $0.92^{\circ} \mathrm{C}$ (John Birks, personal communication).

\section{Results}

\subsection{Diatom assemblages as proxy for paleo-water masses}

Warm Atlantic water carried northward by the IC is the major component of present day surface hydrography over the Reykjanes Ridge (Hopkins, 1991; Fratantoni, 2001). However, proximity to the SAF increase the susceptibility of the core site to subpolar water masses originating from the EGC. In this region the warm and cold waters are mixed together by the circular convergence of the subarctic gyre producing modified North Atlantic Waters (e.g., Reverdin et al., 1999). The different diatom assemblages (factors) serve as a proxy for these different water masses in the area (Fig. 3). The results of the quantitative SST reconstructions and the factor analysis are shown in Fig. $4 a-$ d. Out of the eight different modern diatom assemblages that were established in Andersen et al. (2004), factors 2, 3 and 7 are the primary contributors to the Holocene record of LO09-14 (Figs. 3, 4b-d). The North Atlantic Assemblage (factor 2), mirrors the influence of warm North Atlantic water masses over the site and fluctuations in this factor might indicate variability in the strength of the IC or the progressive cooling or warming 


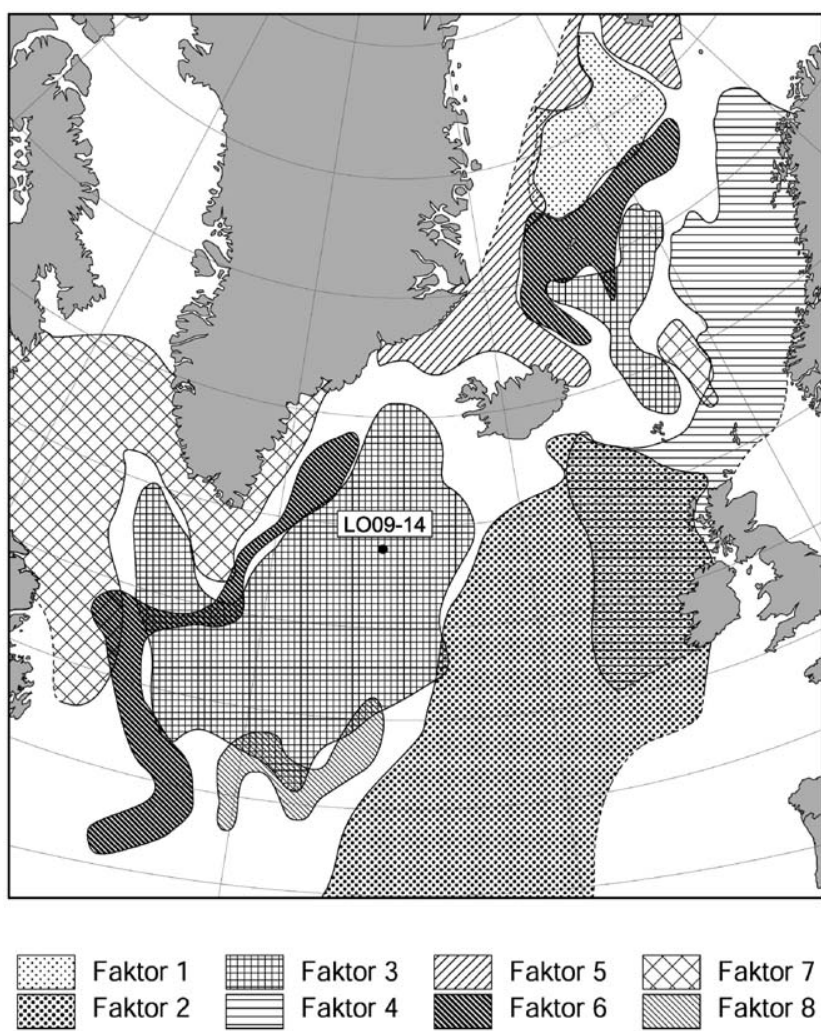

Fig. 3. The modern geographic distribution of the diatom assemblages and the study site LO09-14 (modified from Andersen et al., 2004). Factor $1=$ Greenland Arctic Waters assemblage, Factor $2=$ North Atlantic Current assemblage, Factor $3=$ Subarctic Waters assemblage, Factor $4=$ Norwegian-Atlantic Current assemblage, Factor $5=$ Sea-ice assemblage, Factor $6=$ Arctic Water assemblage, Factor $7=$ East- and West-Greenland Current Assemblage, and Factor $8=$ Transitional Waters assemblage.

of Atlantic water masses. Factor 3 is the Sub-Arctic Assemblage and has its highest loadings in areas of mixture between Arctic and Atlantic waters, such as the present situation at the core site. High presence of factor 3 would thereby indicate conditions similar to the modern. The last significant assemblage is the Eastand West-Greenland Current Assemblage (factor 7), which reflect polar water originating from the EGC or the cold and warm water mixture of the subarctic waters from the area between the WGC and the LC.

\subsection{Reconstruction of paleoceanographic conditions}

The record of factor analysis and the reconstructed SSTs reveal highly variable surface water conditions through the last $11 \mathrm{kyr}$ over the LO09-14 site (Fig. 4a-d). The general Holocene climate development of the site seem to be three-folded in trends and variability: During the early Holocene interval from 11 to $7.5 \mathrm{kyr}$, the surface conditions were highly variable with episodes of temperature fluctuations of $2-4{ }^{\circ} \mathrm{C}$ amplitudes and high amplitude fluctuations in the diatom assemblages.
This unstable period is followed by an interval of increasing SSTs to a Holocene optimum between 7.5 and $5 \mathrm{kyr}$. The final interval from $5 \mathrm{kyr}$ to present reveals cooler and relatively more stable conditions compared to the period between $11-7.5 \mathrm{kyr}$.

\subsubsection{Rhizosolenia borealis and Thalassiothrix longissima events}

The time periods $11-9.5 \mathrm{kyr}, 1.3-0.5 \mathrm{kyr}$ and $2.3 \mathrm{kyr}$ are characterized by several levels where the species Rhizosolenia borealis dominates the assemblages, reaching abundances between $50 \%$ and $90 \%$ of the total floral assemblage (hereafter referred to as $R b$-events). Dense aggregations of the diatom genus Rhizosolenia sp. have been described along a strong convergence zone between warm and cold waters in the equatorial Pacific (Yoder et al., 1994). High concentrations of this species in the subpolar North Atlantic could thereby also imply responses to circulation conditions associated with an open-ocean front, i.e., the SAF. At $2.4 \mathrm{kyr}$ there is also a level where the assemblage is dominated by the species Thalassiothrix longissima (Fig. 4a). Nearly monospecific-dominance of this species is not observed in modern analogues, and our interpretations are therefore again based on comparable counterparts from the Pacific Ocean, but also a thick diatom ooze reported from the subpolar North Atlantic during the last interglacial (Eem) (Bodén and Backman, 1996). The Eemian diatom ooze, consisting exclusively of $T$. longissima, is interpreted to be a result of a proximal convergence front (Bodén and Backman, 1996). Vast deposits of laminated diatom ooze in the equatorial Pacific cores formed during the Neogene by the rapid accumulation of the mat-forming diatom, $T$. longissima. These have also been associated with major frontal systems (Kemp and Baldauf, 1993). Based on the existing information on Rhizosolenia and Thalassiothrix mats we interpret the periods $11-9.5 \mathrm{kyr}, 1.3-0.5 \mathrm{kyr}$ and $2.3-2.4 \mathrm{kyr}$ to be periods where there was exceptionally strong convergence in the surface waters of the northwest Atlantic Ocean.

\subsubsection{A highly unstable Holocene climate}

In the early Holocene (11-7.5 kyr) highly unstable conditions prevailed over the LO09-14 site on the Reykjanes ridge (Fig. 4a-d). From $11 \mathrm{kyr}$ to $10 \mathrm{kyr}$ surface conditions were relatively warm with SSTs between 11 and $13{ }^{\circ} \mathrm{C}$. Several $R b$-events occurred during this interval oscillating with warm water indicative diatoms (factor 2) and the EGC/WGC assemblage (factor 7) implying dynamic surface conditions with subpolar water advecting eastward and possibly the SAF migrating towards the site. A minor cold event around 10.4 precedes an abrupt and a drastic $4{ }^{\circ} \mathrm{C}$ SST drop at $9.8 \mathrm{kyr}$, which led to the coldest Holocene temperature of $8^{\circ} \mathrm{C}$ in the record. This prominent 

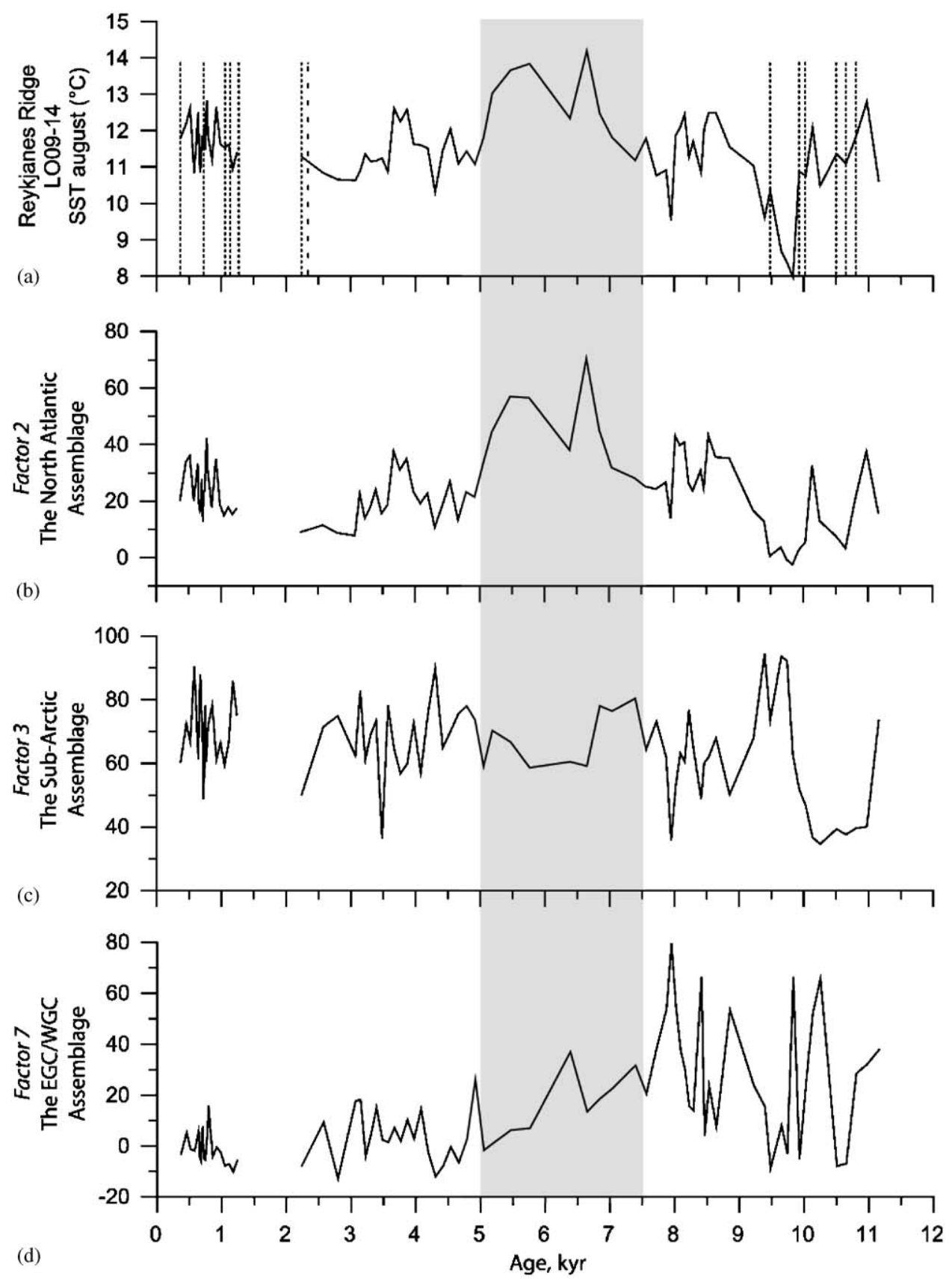

Fig. 4. Reconstructed Holocene sea surface temperatures (SST) for the Reykjanes Ridge site LO09-14 (a) and the variations of loadings of factor 2 (b), 3 (c) and 7 (d). Dotted lines indicate Rb-events (Rhizosolenia borealis dominance) and the dashed line indicates the level of Thalassiothrix longissima dominance. The shaded area indicates the mid-Holocene optimum period.

cooling is associated with total absence of factor 2 and a short-lasting peak of factor 7 followed by the dominance of the Sub-Arctic assemblage (factor 3). $R b$-events are bracketing the cooling with no prominent Rhizosolenia dominance occurring within the maximum cooling. The cooling is thereby not indicating an eastward migrating $\mathrm{SAF}$, but rather a minimum in IC influence as evidenced by the total absence of factor 2. Following the cold event is an increase in SSTs towards temperatures around $12^{\circ} \mathrm{C}$ between 9 and $8 \mathrm{kyr}$. The warming is mirrored by the increasing contribution of factor 2, indicating a stronger IC influence or a progressive surface water warming. A $1.5^{\circ} \mathrm{C}$ SST decrease centred at $8.3 \mathrm{kyr}$ followed by another cooling at $7.9 \mathrm{kyr}$ interrupts this general surface amelioration. Both these SST decreases are associated with high contribution of factor 7 and minor decrease in factor 2. Factor 7 displays a high amplitude variability, which has not been recorded since then, through the whole early Holocene. The record, thus, indicates surface conditions which were much 
more unstable and had a higher polar water imprint than at present. These pulses of factor 7 might reflect a more zonal (eastward) circulation with polar and subpolar water expansion towards the east.

After $7.5 \mathrm{kyr}$ a $2.5^{\circ} \mathrm{C}$ rise over a 500 -year period marks the start of a period of maximum Holocene temperatures (Fig. 4a). SSTs of $13-14{ }^{\circ} \mathrm{C}$ are reached between 7 and $5 \mathrm{kyr}$, which is $2-3{ }^{\circ} \mathrm{C}$ higher than the modern SSTs at this site. This warm interval displays a clear increase in the warm North Atlantic diatom assemblage (factor 2) and a progressive retreat of the East- and West-Greenland Current Assemblage (factor 7) towards modern values. This could imply a stronger IC flow over the site and/or a general warming of the surface water. The lack of $R b$-events through this interval further suggests that the SAF had a more distal position to the study site or that the front was more hampered due to increased surface water mixing. A $1.5^{\circ} \mathrm{C}$ decrease in SSTs centred at $6.4 \mathrm{kyr}$ punctuate this ameliorated interval.

After $5 \mathrm{kyr}$, SSTs decreased and varied between 11 and $13{ }^{\circ} \mathrm{C}$ (Fig. 4a). Surface conditions became relatively stable compared to the early Holocene. Two cooling events around 4.7 and $4.3 \mathrm{kyr}$ are followed by a warm peak centred around $3.7 \mathrm{kyr}$, which precedes a less constrained cooling about $2.8 \mathrm{kyr}$. These cooler surface conditions are reflected by the diminishing influence of warm Atlantic water (factor 2) and the re-establishment of factor 3 as the dominant diatom assemblage over the site (Fig. 4b,c). In the interval $2.3-2.4 \mathrm{kyr}$ there is one $R b$-event, as well as a level of $T$. longissima ooze. Although much shorter in duration than the T. longissima ooze described from Eemian sediments (Bodén and Backman, 1996), the T. longissima-event seen at $2.4 \mathrm{kyr}$ could be a miniature analogue with similar implications of a strong convergence front. From $2-1$ kyr the record has a hiatus, due to intrusion of soupy sediments from the core liner during core sampling. The last $1 \mathrm{kyr}$ of the LO09-14 record is characterized by SSTs varying between 11 and $12.5^{\circ} \mathrm{C}$. Prevailing $R b$-events occur at this time interval, which may indicate the existence of a strongly developed convergence front in the area. To summarize the results; the subpolar North Atlantic seems to have experienced highly variable surface conditions throughout the entire Holocene, but especially during the early Holocene between 11 and $7.5 \mathrm{kyr}$. Repeated cooling events are centred at 10.4, 9.8, 8.3, 7.9, 6.4, 4.7, 4.3 and $2.8 \mathrm{kyr}$. A thermal optimum is recorded between 7.5 and $5 \mathrm{kyr}$.

\section{Discussion and correlations}

Holocene record of SSTs in the Nordic Seas display a development which is closely tied to the history of northern hemisphere high-latitude insolation, though with ca $2 \mathrm{kyr}$ delay due most probably to the persistence of remnants of the Laurentide ice sheet into early Holocene and its effect on the oceanic and atmospheric circulation. In the Nordic Seas a Holocene climatic optimum is recorded between ca 9.5 and $6.5 \mathrm{kyr}$, though displaying a time transgressive behaviour in duration towards the west and north (Koç et al., 1993; Koç and Jansen, 1994; Eiriksson et al., 2000; Birks and Koç, 2002; Marchal et al., 2002). Our results show that the development of climate in the subpolar North Atlantic deviates from the development in the Nordic Seas considering both the timing of the Holocene climate optimum and the stability of the SSTs. Over the Reykjanes site the thermal optimum is not reached until $7.5-5 \mathrm{kyr}$, lagging the insolation maximum by 4000 years.

The differences observed between the early Holocene LO09-14 SST record and SST records further north indicate a decoupling in the surface regimes responsible for the observed variations (Fig. $5 \mathrm{a}-\mathrm{c}$ ). The sites on the North Iceland shelf and the East Greenland shelf reveal evidences for ameliorated surface conditions between 9.5 and $6.5 \mathrm{kyr}$ to which a strong IC is invoked as a possible explanation (Eiriksson et al., 2000; Andersen et al., 2004). The presence of factor 2 in LO09-14 during this time period shows that the Atlantic water inflow is also relatively high over the Reykjanes Ridge (Fig. 4b). However, the amount of cold water ejected into the convergence area south of Iceland was still high as indicated by the high presence of factor 7 (Fig. 4d). This suggests that subpolar/subarctic water weakened the IC influence over the Reykjanes Ridge while the IC had a stronger impact further north. Since the two sites affected by the EGC or EGC-originating water show an early Holocene warming (Fig. 5b,c), the source of cold water over the Reykjanes Ridge probably comes from elsewhere. The answer could lie further south, namely in cold water outflow from the Davis Strait. At present most polar water outflow is through the Fram Strait and Denmark Strait (Aagaard and Carmack, 1989). However, during the early Holocene and until 7-6 kyr the outflow has been suggested to be larger from the Canadian Arctic due to wider channels as a result of isostatic depression (Williams et al., 1995). After the melting of the ice sheets the Canadian Arctic channels became shallower (Williams et al., 1995), establishing the present-day circulation. A sediment core from Orphan Knoll provides evidence for that the early Holocene was characterized by a relatively low salinity until ca $7.5 \mathrm{kyr}$ in this area (Solignac et al., 2004). We, therefore, suggest that the cooler SSTs and the high variability observed in the LO09-14 early Holocene record might be due both to the flux of meltwater from remnants of the Laurentide ice sheet and to the higher polar water flux from the Canadian Arctic. 

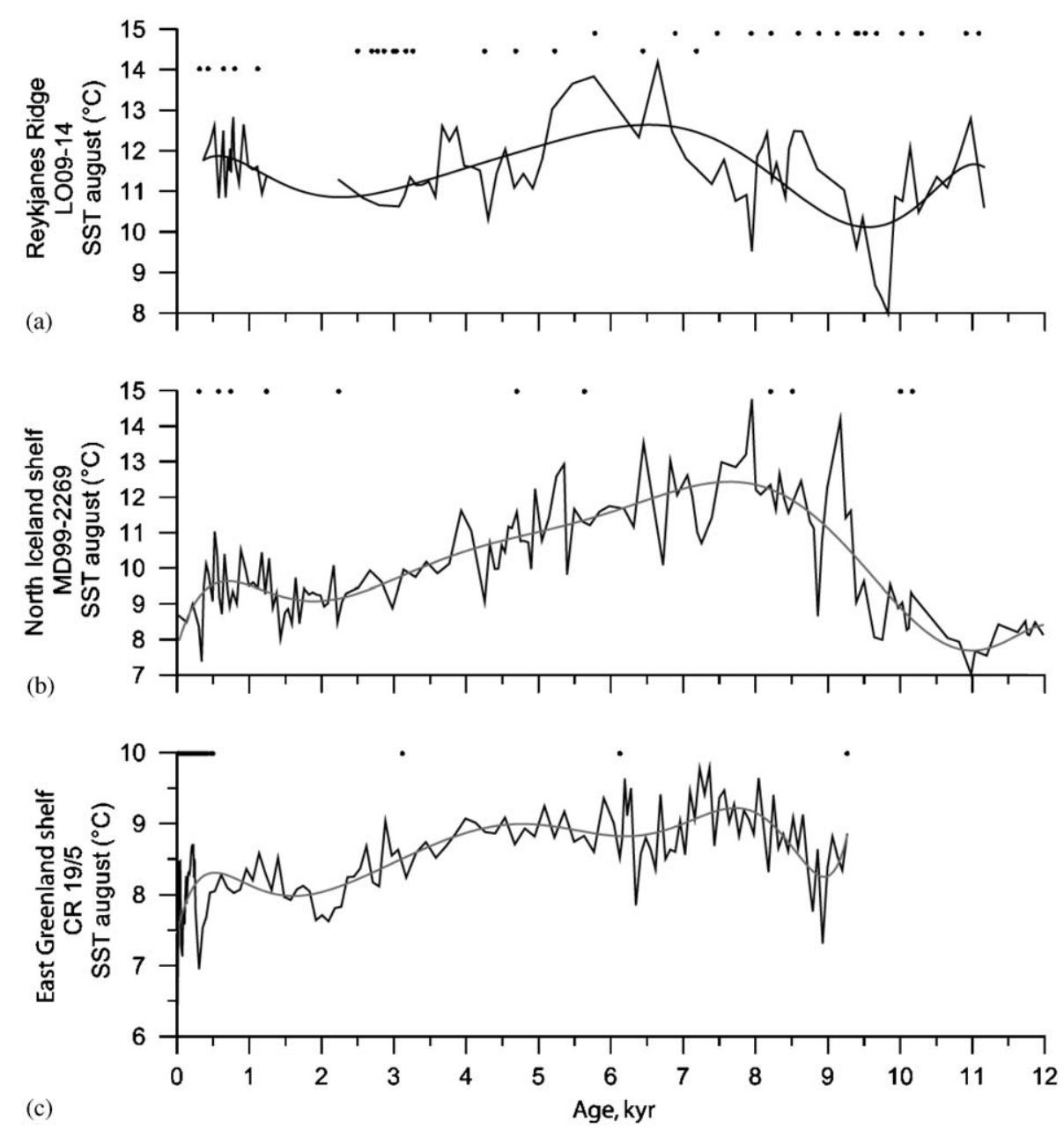

Fig. 5. LO09-14 sea surface temperature (SST) record (a), plotted against SST records from the North Iceland Shelf (b) and the East Greenland Shelf (c) (from Andersen et al., 2004). Dots mark AMS-dates and the black line depicts the Lead 210 measurements.

The different sources of cold water influence and varying warm water contribution over the Reykjanes Ridge site versus the North Iceland shelf site and the East Greenland shelf site is also visible in the temperature gradients $(\Delta T)$ between these sites (Fig. $6 \mathrm{a}, \mathrm{b})$. The modern SSTs reconstructed from the North Iceland shelf is $10^{\circ} \mathrm{C}$ and $8^{\circ} \mathrm{C}$ for the East Greenland shelf, such that the present $\Delta T$ to the Reykjanes Ridge is $2{ }^{\circ} \mathrm{C}$ and $4{ }^{\circ} \mathrm{C}$, respectively. During the early Holocene when the two northerly sites experienced early Holocene climatic optimum reduced or negative temperature gradients are recorded between these sites and the Reykjanes Ridge site. As the thermal optimum was reached over the Reykjanes Ridge site, the transition towards colder surface conditions had already started further north over the EGC-influenced sites. Temperature differences thereby increased between the sites in the time interval 7-5kyr. When the late Holocene cooling was initiated over the Reykjanes Ridge the SST decreased causing reduced $\Delta T$. After $3 \mathrm{kyr}$ the temperature gradients developed towards the present gradient.
A sequence of cold events is observed in the LO09-14 record throughout the Holocene which seem to be part of a larger, regional climate signal. These millennial scale coolings in core LO09-14 are centred at 10.4, 9.8, 8.3, 7.9, 6.4, 4.7, 4.3 and $2.8 \mathrm{kyr}$ (Fig. 7a). These events correlate well with surface ocean perturbations noted as low concentrations of the coccolith Emiliani huxleyi from core MD95-2015 on the Gardar Drift (Giraudeau et al., 2000) (Figs. 1 and 7b). Both the LO09-14 and the MD95-2015 records show some similarities to the stacked record of hematite stained grains (HMG) from the North Atlantic showing that the sea ice events which transported the HMG to the North Atlantic was also accompanied by SST decrease (Fig. 7c) (Bond et al., 1997, 2001). Based on the LO09-14 SST record we can quantify some of these sea ice events to have caused $2-4{ }^{\circ} \mathrm{C}$ cooling of the surface waters. However, the correlation is rather poor in $8-5 \mathrm{kyr}$ interval. This could be due either/both to the stacked nature of the HMG record and chronological uncertainties. The causes of Holocene millennial scale coolings are still under debate. But, both external forces like the sun's radiative output 

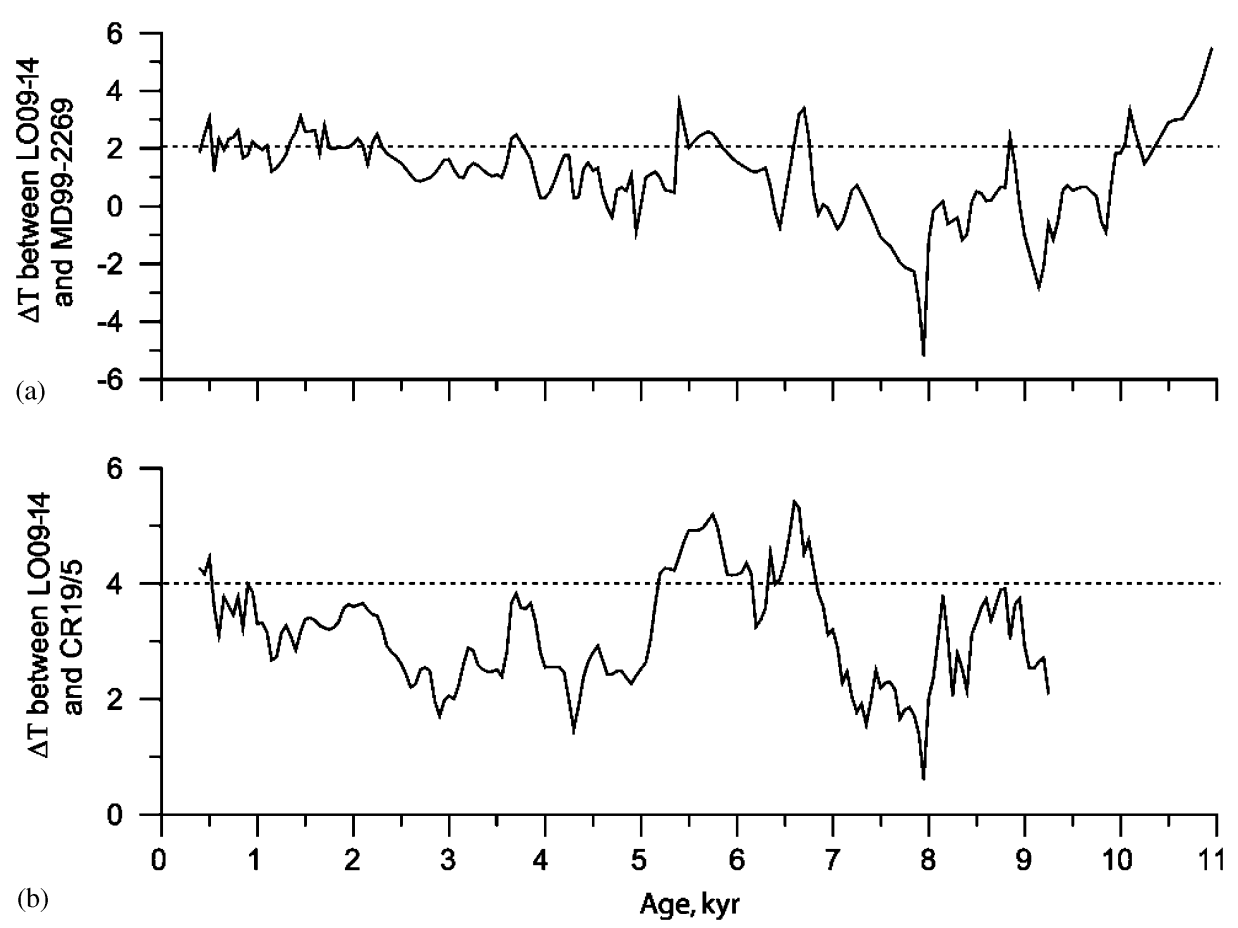

Fig. 6. $\Delta T$ between the interpolated SST curve of LO09-14 and interpolated SST curves from the North Iceland shelf (MD99-2269) (a) and the East Greenland shelf (CR19/5) (b). Dashed line depicts the modern $\Delta T$ between the sites.

(Bond et al., 2001), internal oscillations in the ocean circulation system (Campbell et al., 1998), and largescale variations in atmospheric processes as the North Atlantic Oscillation have been suggested (Giraudeau et al., 2000).

Early Holocene coolings like the $8.2 \mathrm{kyr}$ event, which might correspond to either the 8.3 or the 7.9 cooling in LO09-14, is often attributed to meltwater pulses caused by the decaying Laurentide and Scandinavian ice sheets (Bauch and Weinelt, 1997; Klitgaard-Kristensen et al., 1998; Barber et al., 1999). Frequent presence of similar freshwater episodes in the early Holocene could explain the larger temperature variability recorded in LO09-14 during this period compared to the late Holocene SST.

Deep-water production in the North Atlantic is important for the amount of heat transported northward and for the ocean ventilation. It is therefore considered as an amplifier or causality to millennialscale climate variability during glacial and deglacial time (Broecker, 1990). Deep-water ventilation, however, also varied during the Holocene (Bianchi and McCave, 1999; Oppo et al., 2003). Marine archives record highly unstable deep-water conditions prior to the midHolocene optimum, which are attributed to remnants of ice sheets (Bianchi and McCave, 1999). As the decay of ice sheets stalled, millennial-scale variability still continued. The LO09-14 SST record, which shows evidence for a reduction in IC and an increased cold water influence prior to the mid-Holocene optimum in the subpolar North Atlantic, support changes in circulation as a possible explanation to this variability. A record of carbon-isotope $\left(\delta^{13} \mathrm{C}\right)$ variations from ODP Site 980 in the subpolar northeastern Atlantic (Figs. 1 and 7d) shows reductions in the relative NADW contribution at $9.3,8.0, \quad 5.0$ and $2.8 \mathrm{kyr}$ (Oppo et al., 2003). The observed NADW reductions correlate well with the timing of the surface coolings recorded at the LO09-14 site. When NADW production is low the overturning circulation becomes weaker, hence heat flux transported to the north is decreased. As expected the decreasing NADW contribution from 6.5 to $5.0 \mathrm{kyr}$ is reflected as a cooling from the midHolocene optimum to late-Holocene cooler SSTs at the LO09-14 site. Based on this close correlation, we argue that a surface-deepwater linkage also exists for the Holocene. The trigger for the NADW disturbances could, as discussed by Bond and co-authors (1997, 2001), be an increase in outflow of drift ice from the Fram Strait like the Great Salinity Anomaly in the 1960s and 1970s (Dickson et al., 1988). However, a study from the subarctic Nordic Seas does not reveal variability in the deep-water formation during the last $5 \mathrm{kyr}$ (Bauch et al., 2001), adding to the complexity of the ventilation system. There is no simple one-to-one correlation between the amount of inflowing Atlantic water to the Nordic Seas and the amount of deep-water formation. Instead of participating in the deep-water formation most of the Atlantic water entering the Nordic Seas is modulated to sink to intermediate depths (Mauritzen, 1996). 

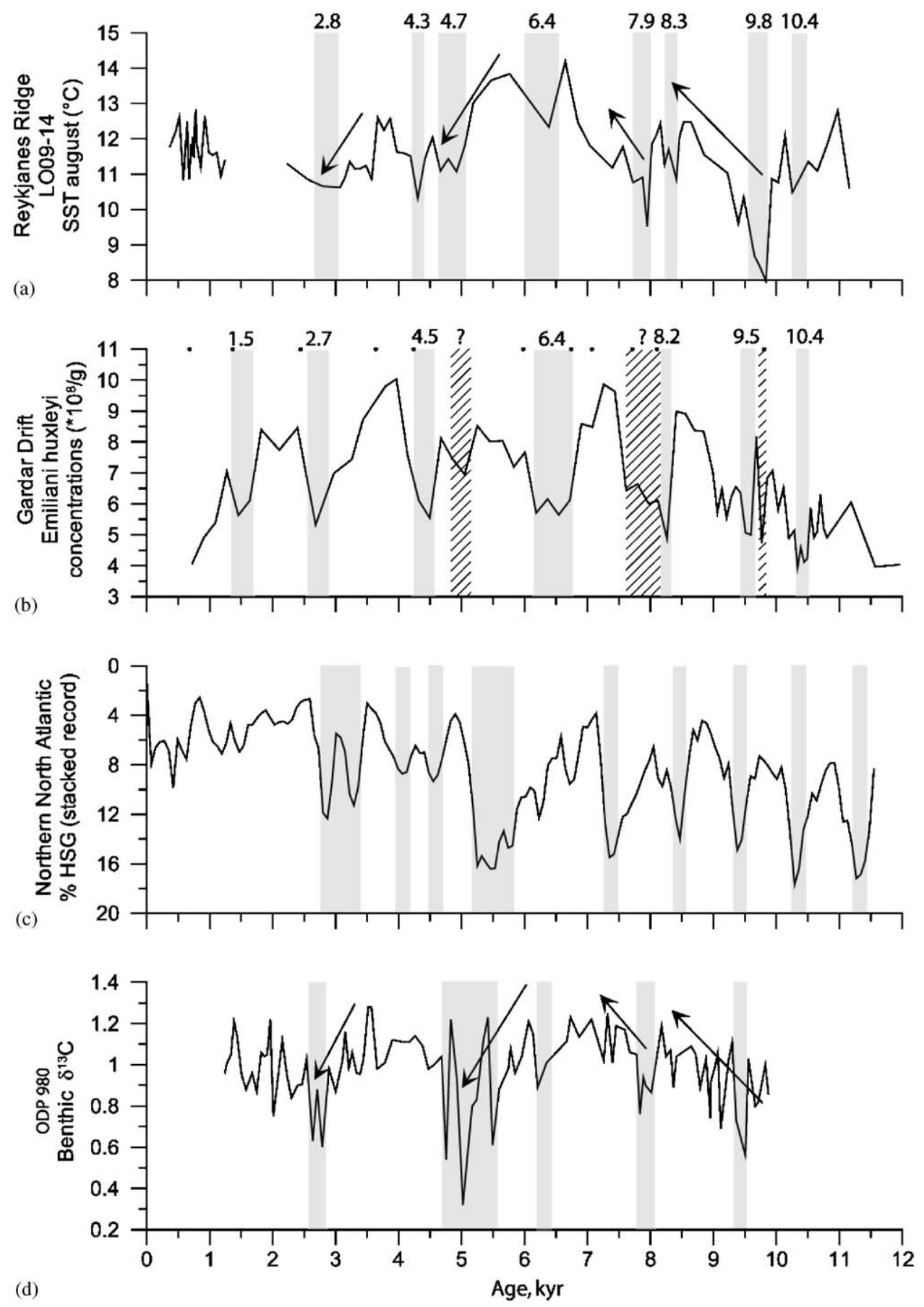

Fig. 7. Comparison of different Holocene climate records from the northern North Atlantic: LO09-14 sea surface temperature (SST) record from Reykjanes Ridge (a); Emiliani huxleyi-events in core MD95-2015 indicating surface perturbations on the Gardar Drift (Giraudeau et al., 2000) (b); Hematite-stained grains (HSG) indicating repeated IRD-events during the Holocene (Bond et al., 1997, 2001) (c); $\delta^{13}$ C from ODP Site 980 as a proxy for North Atlantic Deep Water production (Oppo et al., 2003) (d). The shaded areas show the Holocene cooling events and the hatched areas are possible cold events. The dots in (b) show the AMS-dates in the Gardar Drift record. All records are plotted against age models used by their authors.

Another aspect to the climate system in the subpolar North Atlantic is the recent postulations of deep-water formation in the Irminger Sea (Pickart et al., 2003a). The convection is driven by small-scale inter-annual atmospheric jets formed over the southern tip of Greenland. It is not yet captured in global weather models, but local effects are reported to be strong westerly winds, low air temperatures and heat loss along the $60^{\circ} \mathrm{N}$ parallel (Pickart et al., 2003b). Similar storm events at a larger scale could possibly have defined a stronger configuration to the generally uncertain northernmost branch of the SAF, 
which could explain the recurring $R b$-events between 1.3 and $0.5 \mathrm{kyr}$.

\section{Conclusions}

Our results from the Reykjanes Ridge site show that the Holocene climate developed differently in different regions of the North Atlantic due to different dominant forcing factors. It has been suggested that climate development in the Nordic Seas has been mainly driven by the insolation forcing (e.g., Koç et al., 1993; Koç and Jansen, 1994). Whereas, climate development in the subpolar North Atlantic in proximity of the SAF seems to have been mainly affected by (a) incursions of meltwater from the melting remnants of the Laurentide ice sheet (b) increased outflow of polar water from the Canadian Arctic and (c) variations in the production rate of NADW. Based on our results, we think the western branch of the NAD was reduced due to enhanced meltwater flux from Labrador Sea during the early Holocene and was instead compensated by a stronger eastern branch flowing into the Norwegian Sea. If this is true, then the climate optimum observed in the Nordic Seas during early Holocene is a combination of stronger NAD flux and higher insolation.

The warming in the subpolar North Atlantic, which had been suppressed until about $7 \mathrm{kyr}$ due to the presence of cold and low salinity meltwater, occurs during the mid-Holocene when the northern hemisphere insolation was being strongly reduced. It also starts and ends rather abruptly indicating perhaps a change in atmospheric circulation rather than a gradual insolation forcing. An interesting question to investigate further is whether a long-term NAO/AO type of atmospheric circulation pattern as suggested by Rimbu et al. (2003) can explain the Holocene climate development in the high latitude North Atlantic.

\section{Acknowledgements}

This study was supported by VISTA (in collaboration with Statoil), the Norwegian Research Council through the NOClim and NORPAST projects, the European Commission and the Norwegian Polar Institute. We thank the "LO-14 group": J. McManus, A. Kuijpers, K. Emeis and I. Snowball for good collaboration, K.L. Knudsen and an anonymous reviewer for constructive comments. We also thank E. Jansen and P. de Menocal, coordinators of the IMAGES Holocene Working Group Workshop (Hafslo, August 2003) for a superbly organized meeting. ${ }^{14} \mathrm{C}$ datings were performed at Woods Hole Oceanographic Institute, the University of Aarhus, and at Leibnitz Labor für Altersbestimmung und Isotopenforschung, Christian-Albrechts-Universität, Kiel.

\section{References}

Aagaard, K., Carmack, E.C., 1989. The role of sea ice and other fresh water in the Arctic Circulation. Journal of Geophysical Research 94, 14485-14498.

Alley, R.B., Mayewski, P.A., Sowers, T., Stuiver, M., Taylor, K.C., Clark, P.U., 1997. Holocene climatic instability: a prominent, widespread event $8200 \mathrm{yr}$ ago. Geology 25, 483-486.

Andersen, C., Koç, N., Jennings, A., Andrews, J.T., 2004. Nonuniform response of the major surface currents in the Nordic Seas to insolation forcing: implications for the Holocene climate variability. Paleoceanography 19, PA2003, doi: 10.1029/2002PA000873.

Barber, D.C., Dyke, A., Hillaire-Marcel, C., Jennings, A.E., Andrews, J.T., Kerwin, M.W., Bilodeau, G., McNeely, R., Southons, J., Morehead, M.D., Gagnon, J.-M., 1999. Forcing of the cold event of 8,200 years ago by catastrophic drainage of Laurentide lakes. Nature 400, 344-348.

Bauch, H.A., Weinelt, M.S., 1997. Surface water changes in the Norwegian Sea during last deglacial and Holocene times. Quaternary Science Reviews 16, 1115-1124.

Bauch, H.A., Erlenkeuser, H., Spielhagen, R.F., Struck, U., Matthiessen, J., Thiede, J., Heinemeier, J., 2001. A multiproxy reconstruction of the evolution of deep and surface waters in the subarctic Nordic seas over the last 30,000 yr. Quaternary Science Reviews 20, 659-678.

Bianchi, G.G., McCave, I.N., 1999. Holocene periodicity in North Atlantic climate and deep-ocean flow south of Iceland. Nature 397, 515-517.

Birks, C.J.A., Koç, N., 2002. A high-resolution diatom record of lateQuaternary sea-surface temperatures and oceanographic conditions from the eastern Norwegian Sea. Boreas 31, 323-344.

Bodén, P., Backman, J., 1996. A laminated sediment sequence from the northern North Atlantic Ocean and its climatic record. Geology 24, 507-510.

Bond, G., Showers, W., Cheseby, M., Lotti, R., Almasi, P., deMenocal, P., Priore, P., Cullen, H., Hajdas, I., Bonani, G., 1997. A pervasive millennial-scale cycle in North Atlantic Holocene and glacial climates. Science 278, 1257-1266.

Bond, G., Kromer, B., Beer, J., Muscheler, R., Evans, M.N., Showers, W., Hoffmann, S., Lotti-Bond, R., Hajdas, I., Bonani, G., 2001. Persistent Solar Influence on North Atlantic Climate During the Holocene. Science 294, 2130-2136.

Broecker, W.S., 1990. Salinity history of the northern Atlantic during the last deglaciation. Paleoceanography 5, 459-467.

Bronk Ramsey, C., 1995. Radiocarbon Calibration and Analysis of Stratigraphy: the OxCal Program. Radiocarbon 37, 425-430.

Bronk Ramsey, C., 2001. Development of the Radiocarbon Program OxCal. Radiocarbon 43, 355-363.

Campbell, I.D., Campbell, C., Apps, M.J., Rutter, N.W., Bush, A.B.G., 1998. Late Holocene $\sim 1500 \mathrm{yr}$ climatic periodicities and their implications. Geology 26, 471-473.

Dansgaard, W., Johnsen, S.J., Clausen, H.B., Dahl-Jensen, D., Gundestrup, N.S., Hammer, C.U., Hvidberg, C.S., Steffensen, J.P., Sveinbjörnsdottir, A.E., Jouzer, J., Bond, G., 1993. Evidence for general instability of past climate from a 250-kyr ice-core record. Nature 364, 218-220.

Denton, G.H., Karlén, W., 1973. Holocene climatic variations-Their pattern and possible cause. Quaternary Research 3, 155-205.

Dickson, R.R., Meincke, J., Malmberg, S.A., Lee, A.J., 1988. The "Great Salinity Anomaly" in the Northern North Atlantic 1968-1982. Progress in Oceanography 20, 103-151. 
Dietrich, G., 1969. Atlas of the hydrography of the Northern Atlantic Ocean based on the Polar Front Survey of the International Geophysical Year, winter and summer 1958. International Council for the Exploration of the Sea, Hydrographic Service, Copenhagen.

Eiriksson, J., Knudsen, K.L., Haflidason, H., Henriksen, P., 2000. Late-glacial and Holocene paleoceanography of the North Icelandic shelf. Journal of Quaternary Science 15, 23-42.

Fratantoni, D.M., 2001. North Atlantic surface circulation during the 1990 's observed with satellite-tracked drifters. Journal of Geophysical Research 106, 22,067-22,093.

Giraudeau, J., Cremer, M., Manthé, S., Labeyrie, L., Bond, G., 2000. Coccolith evidence for instabilities in surface circulation south of Iceland during Holocene times. Earth and Planetary Science Letters 179, 257-268.

Hopkins, T.S., 1991. The GIN-Sea-A synthesis of its physical oceanography and literature review 1972-1985. Earth-Science Reviews 30, 175-318.

Hurdle, B.G., 1986. The Nordic Seas. Springer, New York, 777pp.

Jiang, H., Seidenkrantz, M.S., Knudsen, K.L., Eiríksson, J., 2002. Late-Holocene summer sea-surface temperatures based on a diatom record from the north Icelandic shelf. The Holocene 12, $137-147$.

Johannessen, O.M., 1986. Brief overview of the physical oceanography. In: Hurdle, B.G. (Ed.), The Nordic Seas, pp. 103-127.

Kemp, A., Baldauf, J., 1993. Vast Neogene laminated diatom mat deposits from the equatorial Pacific Ocean. Nature 362, 141-143.

Klitgaard-Kristensen, D., Sejrup, H.P., Haflidason, H., Johnsen, S., Spurk, M., 1998. A regional 8200 calyr BP cooling event in northwest Europe, induced by final stages of the Laurentide icesheet deglaciation? Journal of Quaternary Science 13, 165-169.

Klitgaard-Kristensen, D., Sejrup, H.P., Haflidason, H., 2001. The last $18 \mathrm{kyr}$ fluctuations in Norwegian Sea surface conditions and implications for the magnitude of climate change: evidence from the North Sea. Paleoceanography 16, 455-467.

Koç, N., Jansen, E., 1994. Response of the high-latitude Northern Hemisphere to orbital climate forcing: evidence from the Nordic Seas. Geology 22, 523-526.

Koç, N., Jansen, E., Haflidason, H., 1993. Paleoceanographic reconstructions of surface ocean conditions in the Greenland, Iceland and Norwegian Seas through the last $14 \mathrm{ka}$ based on diatoms. Quaternary Science Reviews 12, 115-140.

Koç Karpuz, N., Jansen, E., 1992. A high-resolution diatom record of the last deglaciation from the SE Norwegian Sea: documentation of rapid climatic changes. Paleoceanography 7, 499-520.

Koç Karpuz, N., Schrader, H., 1990. Surface sediment diatom distribution and Holocene paleotemperature variations in the Greenland, Iceland and Norwegian Sea. Paleoceanography 5, $557-580$.

Lehman, S.J., Keigwin, L.D., 1992. Sudden changes in North Atlantic circulation during the last deglaciation. Nature 356, 757-762.
Marchal, O., et al., 2002. Apparent long-term cooling of the sea surface in the northeast Atlantic and Mediterranean during the Holocene. Quaternary Science Reviews 21, 455-483.

Maurtizen, C., 1996. Production of dense overflow waters feeding the North Atlantic across the Greenland-Scotland Ridge. Part 2: an inverse model. Deep-Sea Research 43, 807-835.

Nesje, A., Dahl, S.O., Andersson, C., Matthews, J.A., 2000. The lacustrine sedimentary sequence in Sygneskardvatnet, western Norway: a continuous, high-resolution record of the Jostedalsbreen ice cap during the Holocene. Quaternary Science Reviews 19, 1047-1065.

O’Brien, S.R., Mayewski, P.A., Meeker, L.D., Meese, D.A., Twickler, M.S., Whitlow, S.I., 1995. Complexity of Holocene climate as reconstructed from a Greenland ice core. Science 270, 1962-1964.

Oppo, D.W., McManus, J.F., Cullen, J.L., 2003. Deepwater variability in the Holocene epoch. Nature 422, 277-278.

Pickart, R.S., Straneo, F., Moore, G.W.K., 2003a. Is labrador sea water formed in the irminger basin? Deep-Sea Research I 50, 23-52.

Pickart, R.S., Spall, M.A., Ribergaard, M.H., Moore, G.W.K., Milliff, R.F., 2003b. Deep convection in the Irminger Sea forced by the Greenland tip jet. Nature 424, 152-156.

Reverdin, G., Verbrugge, N., Valdimarsson, H., 1999. Upper ocean variability between Iceland and Newfoundland, 1993-1998. Journal of Geophysical Research 104, 29599-29611.

Rimbu, N., Lohmann, G., Kim, J.-H., Arz, W., Schneider, R., 2003. Arctic/North Atlantic Oscillation signature in Holocene sea surface temperature trends as obtained from alkenone data. Geophysical Research Letters 30 (6), 1280, doi:10.1029/2002GL016570.

Ruddiman, W.F., Glover, L.K., 1975. Subpolar North Atlantic circulation at $9300 \mathrm{yr}$ BP: faunal evidence. Quaternary Research 5, 361-389

Schrader, H.J., Gersonde, R., 1978. Diatoms and silicoflagellates in the eight metres section of the lower Pliocene of Capo Rossello. Utrecht Micropaleontological Bulletin 17, 129-176.

Solignac, S., de Vernal, A., Hillaire-Marcel, C., 2004. Holocene seasurface conditions in the North Atlantic - contrasted trends and regimes in the western and eastern sectors (Labrador Sea vs. Iceland Basin). Quaternary Science Reviews 23, 319-334.

Stefánsson, U., 1962. North Icelandic waters. Journal Marine Research Institute 3, 1-269.

Stuiver, M., Reimer, P.J., Bard, E., Beck, J.W., Burr, G.S., Hughen, K.A., Kromer, B., McCormac, G., van der Plicht, J., Spurk, M., 1998. INTCAL98 Radiocarbon Age Calibration, 24000-0 cal BP. Radiocarbon 40, 1041-1083.

Williams, K.M., Andrews, J.T., Weiner, N.J., Mudie, P.J., 1995. Late Quaternary paleoceanography of the mid- to outer continental shelf, East Greenland. Arctic and Alpine Research 27, 352-363.

Yoder, J.A., Ackleson, S.G., Barber, R.T., Flament, P., Balch, W.M., 1994. A line in the sea. Nature 371, 689-692. 